\title{
SILVER NANOPARTICLES SYNTHESIZED USING CANNABIS SATIVA EXTRACT AND THEIR ANTIBACTERIAL ACTIVITY
}

\author{
'Jana MICHAILIDU, ${ }^{1}$ Alena ČEJKOVÁ \\ ${ }^{1}$ UCT, University of Chemistry and Technology, Prague, Czech Republic, EU, jana.michailidu@vscht.cz
}

https://doi.org/10.37904/nanocon.2020.3744

\begin{abstract}
With growing pressure for wide application of silver nanoparticles, the methods of their production have become increasingly important. Moreover, repurposing waste has been a globally acknowledged trend in the context of circular economy approaches in recent decades. Combining the two, this study presents a facile method of silver nanoparticle production with the help of Cannabis sativa extract originating from a waste product originating from industrial hemp processing. The presence of produced nanoparticles was confirmed using UV-VIS spectrophotometry and TEM. After that, the antimicrobial activity against planktonic cells of an opportunistic pathogenic bacterium, Pseudomonas aeruginosa, was tested using a microcultivation device, Bioscreen C. Our results show Cannabis sativa extract is capable of mediating silver nanoparticle synthesis and stabilization and the produced nanoparticles are able of effectively inhibiting the planktonic cells of all $P$. aeruginosa strains tested. These results suggest there is an economically and environmentally friendly method of silver nanoparticle synthesis for antimicrobial applications.
\end{abstract}

Keywords: Silver nanoparticles, antimicrobial activity, plant extract

\section{INTRODUCTION}

Nanotechnology is a prosperous industry with new potential applications surfacing every year. With nanoparticles being incorporated in mass produced commodities (e.g. clothes [1]) the methods of their production have become a very important topic. As physico-chemical methods of nanoparticle production come with indisputable advantages (e. g. uniform morphology), they definitely also bring about some major setbacks: Physical methods of production often consume great amounts of energy therefore making these approaches expensive, while chemical methods usually require the use of toxic solvents which can sometimes contaminate the product making these nanoparticles unusable in some areas of application [2].

In recent decades, many studies were performed exploring alternative ways of nanoparticle production, some of which take advantage of living organisms or their parts as a mediator for the reduction and stabilization [3]. A successful synthesis of metal nanoparticle was already described not only using microorganisms such as Shewanela algae, Rhodopseudomonas capsulata or Pseudomonas stutzeri [4] but also using extracts from plants, some of which are Pelargonium graveolens, Coriandrum sativum and Eucalyptus hybrida [5].

However, when the materials used for metal ion reduction and nanoparticle stabilization are being chosen, the ecological relevance and sustainability of the approach should be considered. Adhering to the emerging trend of circular economy, considered a priority in a European Commission document "A new Circular Economy Action Plan For a cleaner and more competitive Europe" [6], in various domains of human activity, waste valorization is a key mechanism which needs to be assessed as a desirable approach in as many areas as possible [7]. This is why, in this study, agricultural waste from industrial hemp processing was used for the mediation of nanoparticle production. 


\section{MATERIALS AND METHODS}

\subsection{Materials for nanoparticle synthesis}

Industrial hemp (Cannabis sativa) waste, silver nitrate (Sigma aldrich), ethanol solution (96\%), distilled water.

\subsection{Hemp extract production}

Industrial hemp waste was homogenized using a blender. $150 \mathrm{mg}$ of homogenized hemp were mixed with 600 $\mathrm{ml}$ of $40 \%$ ethanol solution. This mixture was macerated in the dark for $24 \mathrm{~h}$. After that, the extract was filtered through an average laboratory filter $(0.8 \mu \mathrm{m})$ and subsequently through a filter with $0.2 \mu \mathrm{m}$ porosity. The finished extract was stored in dark and cold.

\subsection{Nanoparticle synthesis and detection}

A mixture of $10 \%$ hemp extract and $10 \mathrm{mM}$ of silver nitrate was created and was left to react in dark for $24 \mathrm{~h}$. After that, UV-VIS spectrophotometry was performed to detect the characteristic peaks in a spectral plot (250$700 \mathrm{~nm}$ ). After that a sample of produced nanoparticles was photographed using TEM.

\subsection{Microbial strains and growth media}

Pseudomonas aeruginosa (DBM 3081, DBM 3777, ATCC 10145) glycerol cryopreserves of the microorganisms were stored at $-70^{\circ} \mathrm{C}$. Before the experiment, all $P$. aeruginosa strains were precultivated in Luria-Bertani (LB) liquid medium at $37^{\circ} \mathrm{C}$ and $150 \mathrm{rpm}$ for $24 \mathrm{~h}$ to achieve the exponential phase of growth.

\subsection{Inhibition of planktonic cells of $P$. aeruginosa}

The inhibition of planktonic cells of $P$. aeruginosa strains was determined using a microcultivation device (Bioscreen C, Finland). The cells were cultivated for $24 \mathrm{~h}$ in a microtiter plate in the presence of different $\% \mathrm{v} / \mathrm{v}$ of silver nanoparticles $(0,0.31,0.63,1.25,1.88,2.5,3.13$, and $4.69 \% \mathrm{v} / \mathrm{v})$; each experiment was done in 10 parallels. After that, the growth inhibition was evaluated by plotting the growth intensity for each experiment.

\section{RESULTS AND DISCUSSION}

\subsection{Nanoparticle synthesis and characterization}

During the $24 \mathrm{~h}$ after mixing the silver nitrate solution and hemp extract, the mixture undergone a change of colour; it gradually went from slightly tinted to dark brown. After nanoparticle production was finished, their presence was confirmed using a UV-VIS spectral analysis. This method showed a peak between 400 and $450 \mathrm{~nm}$ which is characteristic of silver nanoparticles according to literature [8]. Subsequently, TEM was performed (Figure 1) and it revealed the nanoparticles produced are characterized by high polydispersity, varying morphology and sizes between 5 to $80 \mathrm{~nm}$. In a study by Ahmed et al. (2015) silver nanoparticles were produced using Azadirachta indica leaf extract; the nanoparticles also exhibited high polydispersity and the diameters ranged between 8 and $100 \mathrm{~nm}$ [9]. In another study, silver nanoparticle production was mediated by Chenopodium murale leaf extract and the nanoparticle size varied between 30 and $50 \mathrm{~nm}$ [10].

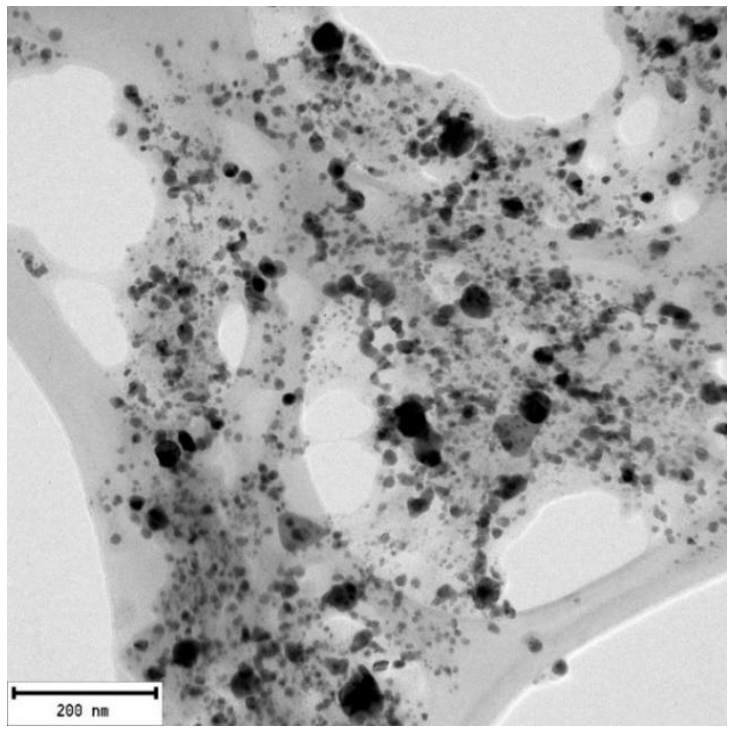

Figure 1 TEM photograph of nanoparticles formed using Cannabis sativa extract 


\subsection{Planktonic cell inhibition}

When observing the antibacterial activity of produced nanoparticles against planktonic cells of $P$. aeruginosa (DBM 3081) and $P$. aeruginosa (DBM 3777), more than $90 \%$ inhibition was achieved in the presence of $0.31 \%$ v/v (Figure 2 and Figure 3).

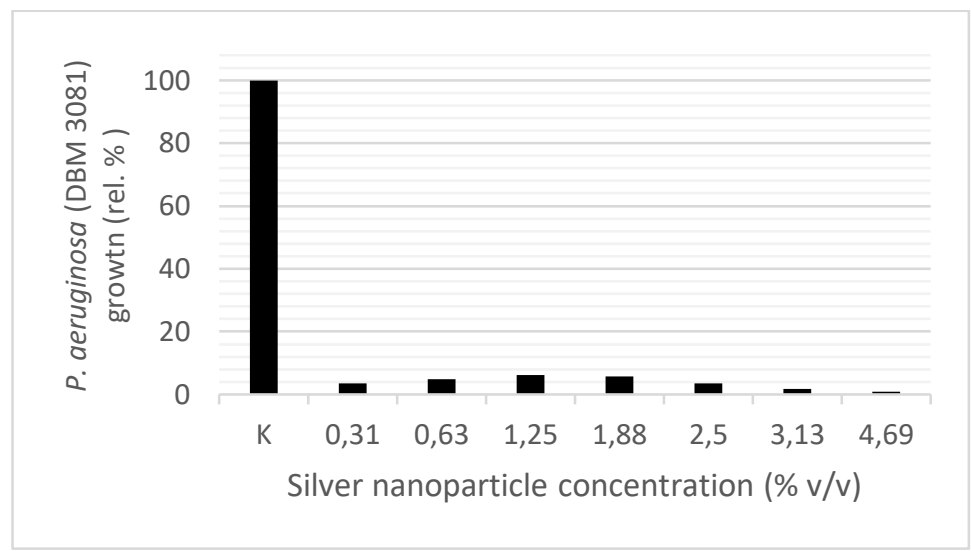

Figure 2 Growth inhibition of $P$. aeruginosa (DBM 3081) planktonic cells mediated by silver nanoparticles; $\mathrm{K}$ - control experiment $(0 \% \mathrm{v} / \mathrm{v}$ of nanoparticles)

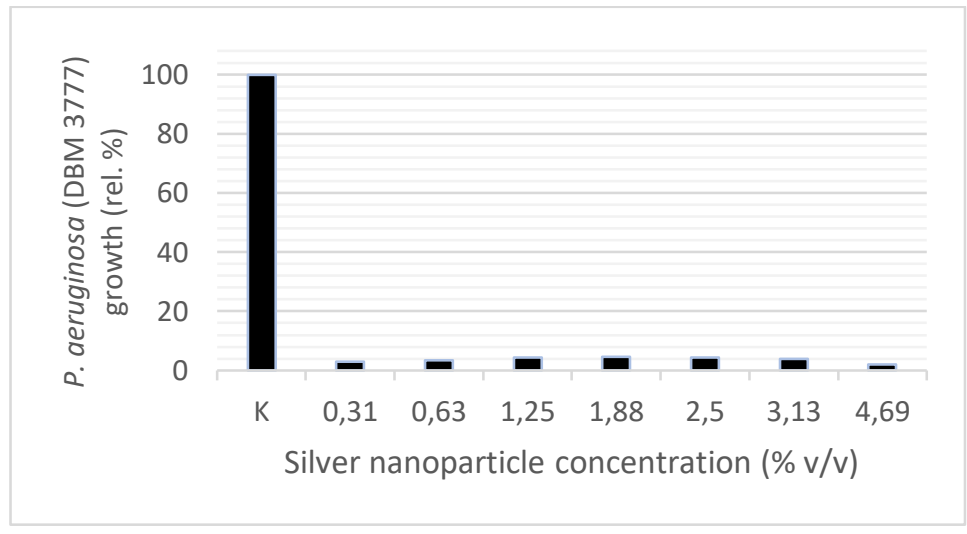

Figure 3 Growth inhibition of $P$. aeruginosa (DBM 3777) planktonic cells mediated by silver nanoparticles;

$\mathrm{K}$ - control experiment $(0 \% \mathrm{v} / \mathrm{v}$ of nanoparticles)

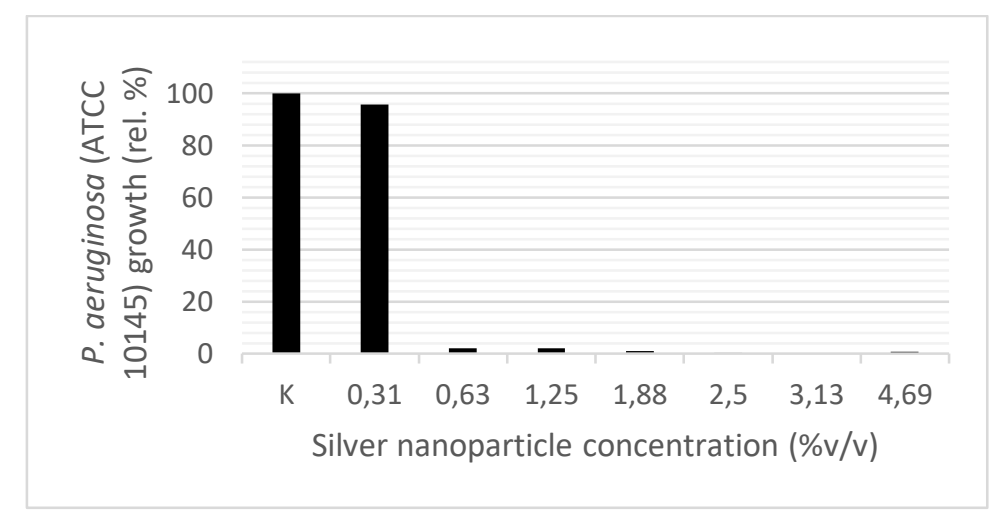

Figure 4 Growth inhibition of $P$. aeruginosa (ATCC 10145) planktonic cells mediated by silver nanoparticles; $\mathrm{K}$ - control experiment $(0 \% \mathrm{v} / \mathrm{v}$ of nanoparticles) 
In the case of $P$. aeruginosa (ATCC 10145), $90 \%$ inhibition of planktonic cell growth was achieved when $0.63 \% \mathrm{v} / \mathrm{v}$ of produced nanoparticles was used (Figure 4).

Our results showed the nanoparticles produced were very effective at the inhibition of planktonic cells of a gram-negative bacterium $P$. aeruginosa. This corresponds with the scientific understanding of the interaction of a microbial cell and silver nanoparticles. All silver nanoparticles interfere with the microbial cell predominantly by the mechanism of in situ silver ion release. However, with nanoparticles of a diameter smaller than $10 \mathrm{~nm}$, the disruption of intracellular processes is mediated by the nanoparticle itself [11].

Antimicrobial activity of silver nanoparticles produced by "green" syntheses was already described in literature. A study was conducted where silver nanoparticles were produced using a culture supernatant of Nocardiopsis sp. MBRC-1 and their antimicrobial activity against clinically relevant strains of pathogenic microorganisms such as Bacillus subtilis and Candida albicans was demonstrated [12]. In another study, silver nanoparticles were produced using Salvia spinosa extract with their antimicrobial activity being proved against Bacillus subtilis and Escherichia coli [13].

\section{CONCLUSION}

In this study, it was found that agricultural waste originating from Cannabis sativa plants can be used for the production of an extract capable of mediating "green" synthesis of silver nanoparticles. Moreover, these nanoparticles were able to inhibit the planktonic cell growth of an opportunistic human pathogen, $P$. aeruginosa. This approach to silver nanoparticle production could be used in the context of various applications (e. g. antimicrobial coating of surfaces) in order to adhere to the principles of circular economy.

\section{ACKNOWLEDGEMENTS}

\section{This work was supported from the grant of Specific university research - grant No A2_FPBT_2020_006}

\section{REFERENCES}

[1] MItRANO, D.M., RIMMELE, E., WICHSER, A., ERNI, R., HEIGHT, M., NOWACK, B. Presence of Nanoparticles in Wash Water from Conventional Silver and Nano-silver Textiles. ACS Nano. 2014, vol. 8, no. 7, pp. 7208-7219.

[2] SINGH, J., DUTTA, T., KIM, K.-H., RAWAT, M., SAMDDAR, P., KUMAR, P. 'Green' synthesis of metals and their oxide nanoparticles: applications for environmental remediation. Journal of Nanobiotechnology. 2018, vol. 16, no. 84, pp. 1-24.

[3] SRIKAR, S.K., GIRI, D.D., PAL, D.B., MISHRA, P.K., UPADHYAY, S.N. Green Synthesis of Silver Nanoparticles: A Review. Green and Sustainable Chemistry. 2016, vol. 6, no. 1, pp. 34-56.

[4] PARK, T.J., LEE, K.G., LEE, S.Y. Advances in microbial biosynthesis of metal nanoparticles. Applied Microbiology and Biotechnology. 2016, vol. 100, pp. 521-534.

[5] IRAVANI, S. Green synthesis of metal nanoparticles using plants. Green Chemistry. 2011, vol. 13, pp. $2638-2650$.

[6] EUR-LEX. Communication from the Commission to the European Parliament, the Council, the European Economic and Social Committee and the Committee of the Regions. A new Circular Economy Action Plan for a cleaner and more competitive Europe. [online]. Brussels, 2020. [viewed 2020-10-09]. Available from: https://eurlex.europa.eu/resource.html?uri=cellar:9903b325-6388-11ea-b735-01aa75ed71a1.0017.02/DOC 1\&format=PDF.

[7] PATWA, N., SIVARAJAH, U., SEETHARAMAN, A., SARKAR, S., MAITI, K., HINGORANI, K. Towards a circular economy: An emerging economies context. Journal of Business Research. [online]. 2020, vol. 122, pp 725-735. Available from: https://doi.org/10.1016/j.jbusres.2020.05.015.

[8] BHUI, D.K., BAR, H., SARKAR, P., SAHOO, G.P., DE, S.P., MISRA, A. Synthesis and UV-vis spectroscopic study of silver nanoparticles in aqueous SDS solution. Journal of Molecular Liquids. 2009, vol. 145, no. 1, pp. 3337. 
[9] AHMED, S., SAIFULLAH, AHMAD, M., SWAMI, B.L., IKRAM, S. Green synthesis of silver nanoparticles using Azadirachta indica aqueous leaf extract. Journal of Radiation Research and Applied Sciences. 2016, vol. 9, no. 1, pp. 1-7.

[10] ABDEL-AZIZ, M.S., SHAHEEN, M.S., EL-NEKEETY, A.A., ABDEL-WAHHAB, M.A. Antioxidant and antibacterial activity of silver nanoparticles biosynthesized using Chenopodium murale leaf extract. Journal of Saudi Chemical Society. 2014, vol. 18, no. 4, pp. 356-363.

[11] DURÁN, N., DUÁN, M., DE JESUS, M.B., SEABRA, A.B., FÁVARO, W.J., NAKAZATO, G. Silver nanoparticles: A new view on mechanistic aspects on antimicrobial activity. Nanomedicine: Nanotechnology, Biology and Medicine. 2016, vol. 12, no. 3, pp. 787-799.

[12] MANIVASAGANM P., VENKATESAN, J., SENTHILKUMAR, K., SIVAKUMAR, K., KIM, S.-K. Biosynthesis, Antimicrobial and Cytotoxic Effect of Silver Nanoparticles Using a Novel Nocardiopsis sp. MBRC-1. BioMed Research International. Biotechnology and Green Chemistry. 2013, vol. 2013, article no: 287638.

[13] PIRTARIGHAT, S., GHANNADNIA, M., BAGHSHAHI, S. Green synthesis of silver nanoparticles using the plant extract of Salvia spinosa grown in vitro and their antibacterial activity assessment. Journal of nanostructure Chemistry. 2019, vol. 9, pp. 1-9. 